\title{
Prostate cancer management challenges due to COVID-19 in countries with low-to-middle-income economies: $A$ radiation oncology perspective
}

\section{Desafíos de los países con economías de bajo-a-mediano ingreso para el manejo del cáncer de próstata por la pandemia por COVID-19: La perspectiva del Oncólogo Radioterápico} iDMaría Caicedo-Martínez, ${ }^{1}$ iD Alejandro González-Motta, ${ }^{1}$ iD Sebastián R Gil-Quiñones, ${ }^{2}$
(iD Juan Carlos Galvis. ${ }^{{ }^{*}}$

Keywords:

Developing countries, Radiotherapy, Prostate tumor, COVID-19

Correspondencia: *Juan Carlos Galvis. Carrera 16 número 84 interior 09 Bogotá,

Colombia Correo Electrónico: jcgalvis@ husi.org.com, juangalvis@me.com

\section{Abstract}

Description: The COVID-19 pandemic poses an unprecedented challenge for urologic oncology and radiotherapy. Radiation oncology departments and international collaboration groups are sharing their management adaptations made in response to the pandemic. The present narrative review summarizes the current recommendations.

Relevance: There is a need to define which patients are candidates for safe treatment delay until the pandemic is over or controlled, to reduce exposure to the virus in the healthcare personnel and patients.

Conclusions: Telemedicine is recommended for follow-up visits. Active surveillance is the preferred treatment for patients with favorable intermediate risk. In greater risk disease, hormone therapy safely postpones radiotherapy up to 7 months. Radiosurgery is suggested in centers that have the necessary technology and previous experience. A moderately hypofractionated regimen is recommended if radiosurgery/ultra-hypofractionation is not available. Hypofractionation should be implemented if image-guided radiation therapy is already in place. Countries with low and middle-income economies face challenges in adopting the recommendations for prostate cancer management during the pandemic. Postponing treatment may result in the overwhelming of radiation oncology center capacity, after the pandemic.

Citación: Caicedo-Martínez M., González-Motta A., Gil-Quiñones S. R., Galvis J. C. Low- Middle Income Countries Challenges for Prostate Cancer management during COVID-19: from the Radiation Oncologist Perspective. Rev. Mex. Urol. 2020;80(4):pp 1-14

\footnotetext{
${ }^{1}$ Pontificia Universidad Javeriana, Bogotá, Colombia.

${ }^{2}$ Fundación Universitaria de Ciencias de la Salud, Bogotá, Colombia.
}

Recepción: 25 de mayo de 2020 Aceptación: 19 de julio de 2020

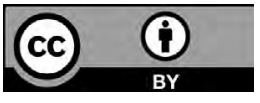




\section{Desafíos de los países con economías de bajo-a-mediano ingreso para el manejo... Caicedo-Martínez M., et al.}

Palabras clave:

Países en desarrollo, radioterapia, neoplas-

ma prostático, COVID-19

\section{Resumen}

Descripción: El COVID-19 representa un desafío para la práctica de la urología oncológica y radioterapia. Departamentos y grupos de colaboración internacional de radio oncología están compartiendo sus adaptaciones de práctica en respuesta a la pandemia. Esta revisión narrativa resume las recomendaciones actuales.

Relevancia: Existe la necesidad de definir qué pacientes son candidatos para un retraso seguro en el tratamiento hasta que la pandemia termine o se controle, de forma que se minimice la exposición del personal de salud y de los pacientes.

Conclusiones: Se recomienda la telemedicina para visitas de seguimiento. La vigilancia activa es el tratamiento preferido para el riesgo intermedio favorable. En enfermedad de mayor riesgo, la hormonoterapia retrasa la radioterapia de forma segura hasta 7 meses. La radiocirugía se sugiere en centros con tecnología y experiencia previa. Se recomienda un régimen de hipofraccionamiento moderado si no se dispone de radiocirugía / ultra hipofraccionamiento. El hipofraccionamiento debe implementarse si las capacidades de IGRT ya están en su lugar. Los países de bajos y medianos ingresos enfrentan desafíos para adaptar las recomendaciones para el manejo del cáncer de próstata durante la pandemia. El aplazamiento del tratamiento puede exceder la capacidad de los centros de oncología radioterápica después de la pandemia.

\section{Introduction}

From the time the first patient was diagnosed with SARS-CoV-2 in Wuhan, China, incidence rates have risen rapidly in countries all over the world. ${ }^{(1)}$ The current SARS-CoV-2 pandemic poses an unprecedented challenge for cancer management. Cancer patients have become a highly vulnerable population during the pandemic.(2) Oncologists need to ensure a safer approach and direct strategies to prevent the exposure of patients to the virus, while continuing to manage oncologic disease. ${ }^{(3)}$ Of the cancer treatment services, radiotherapy faces a unique challenge in managing cancer patients during the pandemic, given that a majority of treatments need to be delivered daily.

There are unique radiotherapeutic considerations in the management of prostate cancer. Overall prognosis is generally favorable, enabling the delay of radiation in a selected population, in times of crisis. ${ }^{(4,5)}$ Prostate cancer is the most common cancer in men. Although countries with high-income economies (HIEs) report higher incidence rates than countries with low and middle-income economies (LMIEs), the latter have higher mortality-to-incidence ratios. ${ }^{(6,7)}$ Because more cases are 
Desafíos de los países con economías de bajo-a-mediano ingreso para el manejo... Caicedo-Martínez M., et al.

diagnosed in the late stage of disease, radiation treatment is fundamental in the management of those patients. ${ }^{(8)}$ There is a pressing demand to define which patients require urgent or nonurgent treatment (including a 2 to 4 -month delay), until the pandemic is over, or at least controlled. ${ }^{(9,10)}$

The development of novel public health protocols and the consequent modification of cancer centers are both a challenge and an opportunity. Global initiatives to ensure adequate prostate cancer treatment are arising in response to the COVID-19 pandemic. ${ }^{(11,12)}$ Nevertheless, health systems and cancer care facilities in the countries with LMIEs have particularities that need to be considered when providing a recommendation for oncology care, in response to SARS-CoV-2.

We summarize herein the available radiation therapy recommendations for prostate cancer during the pandemic and provide recommendations for their implementation in radiation oncology centers in countries with (LMIEs).

\section{Methods}

We conducted a search in the PubMed electronic database (via Medline) on April 11, 2020, that was supplemented by a review of journal articles in the COVID-19 portal of the American Society of Radiation Oncology (available at URL: https://www.astro.org/Daily-Practice/COVID-19-Recommendations-and-Information/Journal-Articles). No language or publication status restrictions were imposed. Date stipulations included studies published between December 2019 (according to the first diagnosis of the new SARS-CoV-2) and April
11, 2020 (date of the search). The search terms were "COVID-19" OR "SARS-CoV-2" AND "Cancer" OR "Neoplasm" OR "Tumor" AND "Radiotherapy." We included all articles reporting on practice recommendations for prostate cancer during the COVID-19 pandemic, as well as articles that considered multiple types of neoplasms, whenever they had specific prostate cancer recommendations. We excluded studies that did not include radiation therapy considerations and only assessed surgical or chemotherapy recommendations. Two of the authors (MC and SG) carried out the screening of titles and abstracts to minimize selection bias.

\section{Results}

Of the 2231 screened titles and abstracts, seven articles were selected. The analyses reviewed included 2 studies from international collaborations (multi-continent), ${ }^{10,11)} 1$ national oncology guideline from Spain, ${ }^{(12)} 2$ national collaborations from Europe (Germany $\mathrm{n}=1$, Italy $\mathrm{n}=1) .{ }^{(13,14)}$ The remaining articles were institutional recommendations from two European countries (Switzerland and Italy). ${ }^{(15,16)}$ No LMIE-based study met our inclusion criteria. Of the studies included, only two exclusively addressed prostate cancer. ${ }^{(11,12)}$ General recommendations for facing the pandemic were also provided by all studies and are summarized in Table 1.

Four of the studies included presented prostate cancer recommendations by stage of the disease. Recommendations are presented in Table 2 and the hypofractionation schedules in Table 3. 
Table 1: Summary of recommendations

\begin{tabular}{|c|c|c|c|}
\hline $\begin{array}{l}\text { Author } \\
\text { Publication Date } \\
\text { Institution } \\
\text { Country }\end{array}$ & $\begin{array}{l}\text { Type of } \\
\text { neoplasm }\end{array}$ & $\begin{array}{c}\text { Practice recommendations for } \\
\text { prostate cancer }\end{array}$ & $\begin{array}{l}\text { General practice } \\
\text { recommendations }\end{array}$ \\
\hline $\begin{array}{l}\text { Achard V et al. } \\
\text { 2020.(16) } \\
\text { Geneva University Hospital, } \\
\text { Geneva, Switzerland }\end{array}$ & $\begin{array}{l}\text { Multiple } \\
\text { neoplasms }\end{array}$ & Hypofractionation, when feasible & $\begin{array}{l}\text { Prioritization of treatments } \\
\text { Postponement of non-vital } \\
\text { procedures } \\
\text { Postponement of } \\
\text { nonessential visits }\end{array}$ \\
\hline $\begin{array}{l}\text { Portaluri M et al. } \\
2020 .^{(17)} \\
\text { A. Perrino Hospital } \\
\text { Italy }\end{array}$ & $\begin{array}{l}\text { Multiple } \\
\text { neoplasms }\end{array}$ & $\begin{array}{l}\text { Postoperative RT: two-week } \\
\text { postponement } \\
\text { Prostate cancer under ADT*: two- } \\
\text { week postponement }\end{array}$ & $\begin{array}{l}\text { Postponement of control } \\
\text { visits } \\
\text { Reduction of treatments per } \\
\text { day ( } 3 \text { sessions per hour) }\end{array}$ \\
\hline $\begin{array}{l}\text { Filippi AR et al. } \\
2020 .^{(15)} \\
\text { Multiple institutions } \\
\text { Italy }\end{array}$ & $\begin{array}{l}\text { Multiple } \\
\text { neoplasms }\end{array}$ & $\begin{array}{l}\text { Delay RT for low/intermediate risk } \\
\text { prostate disease }\end{array}$ & $\begin{array}{l}\text { Adopt hypofractionated } \\
\text { schedules } \\
\text { Postponement of follow-up } \\
\text { visits }\end{array}$ \\
\hline $\begin{array}{l}\text { Simcock R et al. } \\
2020 .^{(11)} \\
\text { Radiation Oncology Journal } \\
\text { Club Community } \\
\text { International collaboration }\end{array}$ & $\begin{array}{l}\text { Multiple } \\
\text { neoplasms }\end{array}$ & $\begin{array}{l}\text { Omit RT in low and favorable } \\
\text { intermediate risk } \\
\text { Omit RT for oligometastatic prostate } \\
\text { cancer }\end{array}$ & $\begin{array}{l}\text { Telephone follow-up and/ } \\
\text { or consultation } \\
\text { Prioritization of treatments } \\
\text { Postponement of radical } \\
\text { treatments when biology } \\
\text { permits the delay }\end{array}$ \\
\hline $\begin{array}{l}\text { Zaorsky NG et al. } \\
\text { 2020.(12) } \\
\text { International collaboration } \\
\text { United States - United } \\
\text { Kingdom }\end{array}$ & Prostate & $\begin{array}{l}\text { Delay RT for very low, low, and } \\
\text { favorable intermediate-risk disease } \\
\text { Use ADT to delay RT for } 4-6 \text { months } \\
\text { in unfavorable intermediate- } \\
\text { risk, high-risk, N+, postoperative } \\
\text { recurrence, oligometastatic, and } \\
\text { low-volume M1 disease. }\end{array}$ & $\begin{array}{l}\text { Remote visits } \\
\text { Avoid radiation } \\
\text { Postpone radiation } \\
\text { Shorten radiation }\end{array}$ \\
\hline $\begin{array}{l}\text { Combs SE et al. } \\
\text { 2020.(14) Multiple institutions } \\
\text { Germany }\end{array}$ & $\begin{array}{l}\text { Multiple } \\
\text { neoplasms }\end{array}$ & $\begin{array}{l}\text { Consider hypofractionated regimens } \\
\text { Delay RT with ADT or active } \\
\text { surveillance in low risk disease. } \\
\text { Delay RT with ADT for } 2 \text { to } 3 \\
\text { months in intermediate-risk or high- } \\
\text { risk disease } \\
\text { Consider watchful waiting or ADT } \\
\text { in salvage situations }\end{array}$ & $\begin{array}{l}\text { Personnel, patient, and } \\
\text { device hygiene } \\
\text { Implementation of a } \\
\text { management team } \\
\text { Division of management } \\
\text { team ( } 50 \% \text { on site, } 50 \% \text { off } \\
\text { site) } \\
\text { Identify and treat critical } \\
\text { cases (ensure triage for } \\
\text { SARS-CoV-2) }\end{array}$ \\
\hline $\begin{array}{l}\text { Gomez-Iturriaga } \\
\text { A et al. 2020.(13) } \\
\text { URONCOR - SEOR } \\
\text { Spain }\end{array}$ & Prostate & $\begin{array}{l}\text { Delay RT treatment ( } 3-12 \text { months) } \\
\text { for very low, low, and intermediate } \\
\text { favorable risk. } \\
\text { Consider active surveillance. } \\
\text { Use hypofractionated regimen } \\
\text { (SBRT or ultra-hypofractionation) + } \\
\text { Unfavorable intermediate, high, and } \\
\text { very high-risk: start ADT (use as } \\
\text { neoadjuvant treatment to delay RT } 2 \\
\text { to } 6 \text { months) }\end{array}$ & $\begin{array}{l}\text { During the pandemic: } \\
\text { Avoid hospital visits } \\
\text { (telemedicine for follow- } \\
\text { up, in-treatment, and first } \\
\text { consultation visits) } \\
\text { Delay PSA control for 3-6 } \\
\text { months }\end{array}$ \\
\hline
\end{tabular}

ADT: Antigen Deprivation Therapy, AS: Active Surveillance, Fx: Fraction. PSA: Prostate-Specific Antigen. RT: Radiation Therapy. SBRT: Stereotactic Body Radiation Therapy.

*No other specification

† If previous experience and available technology 


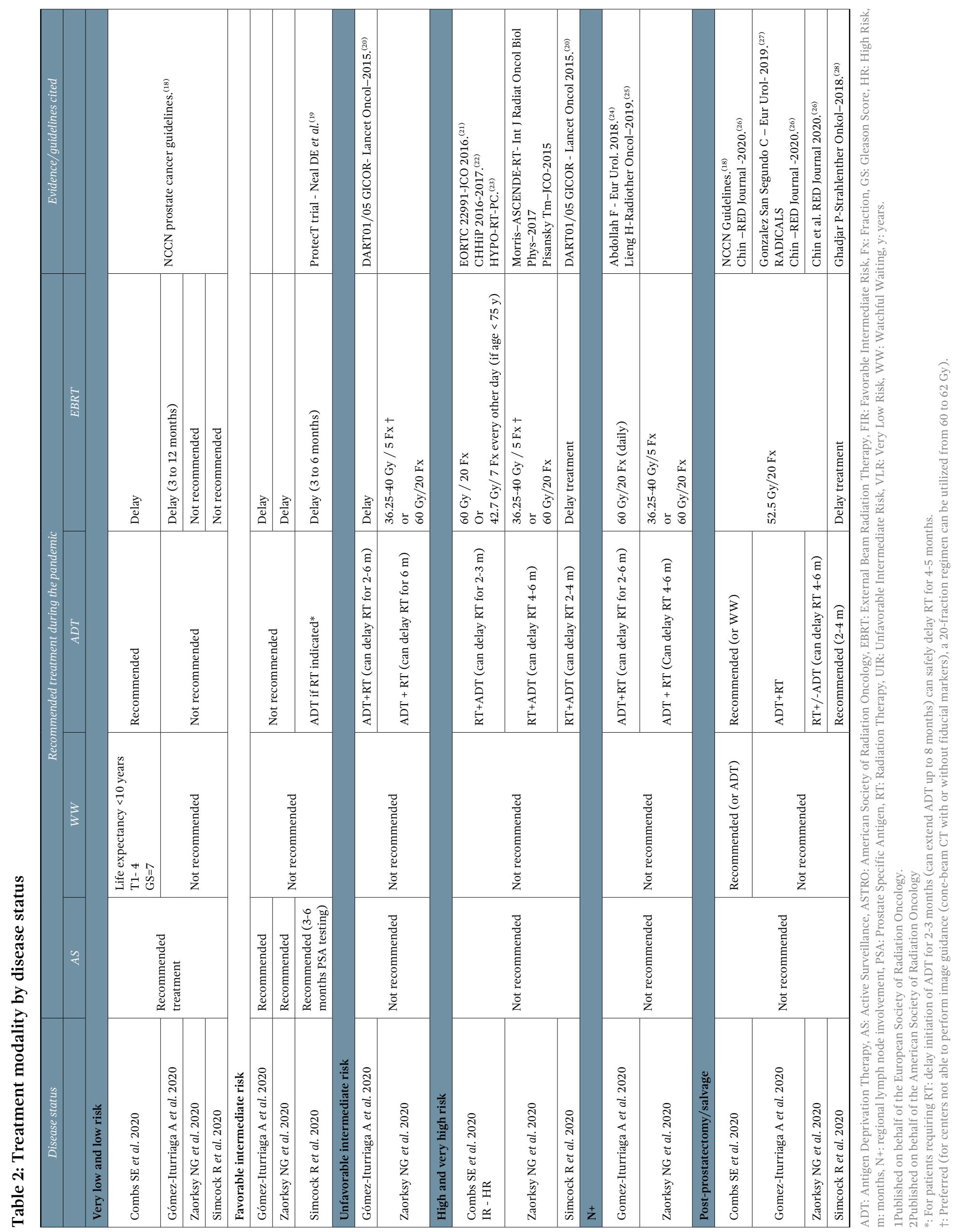




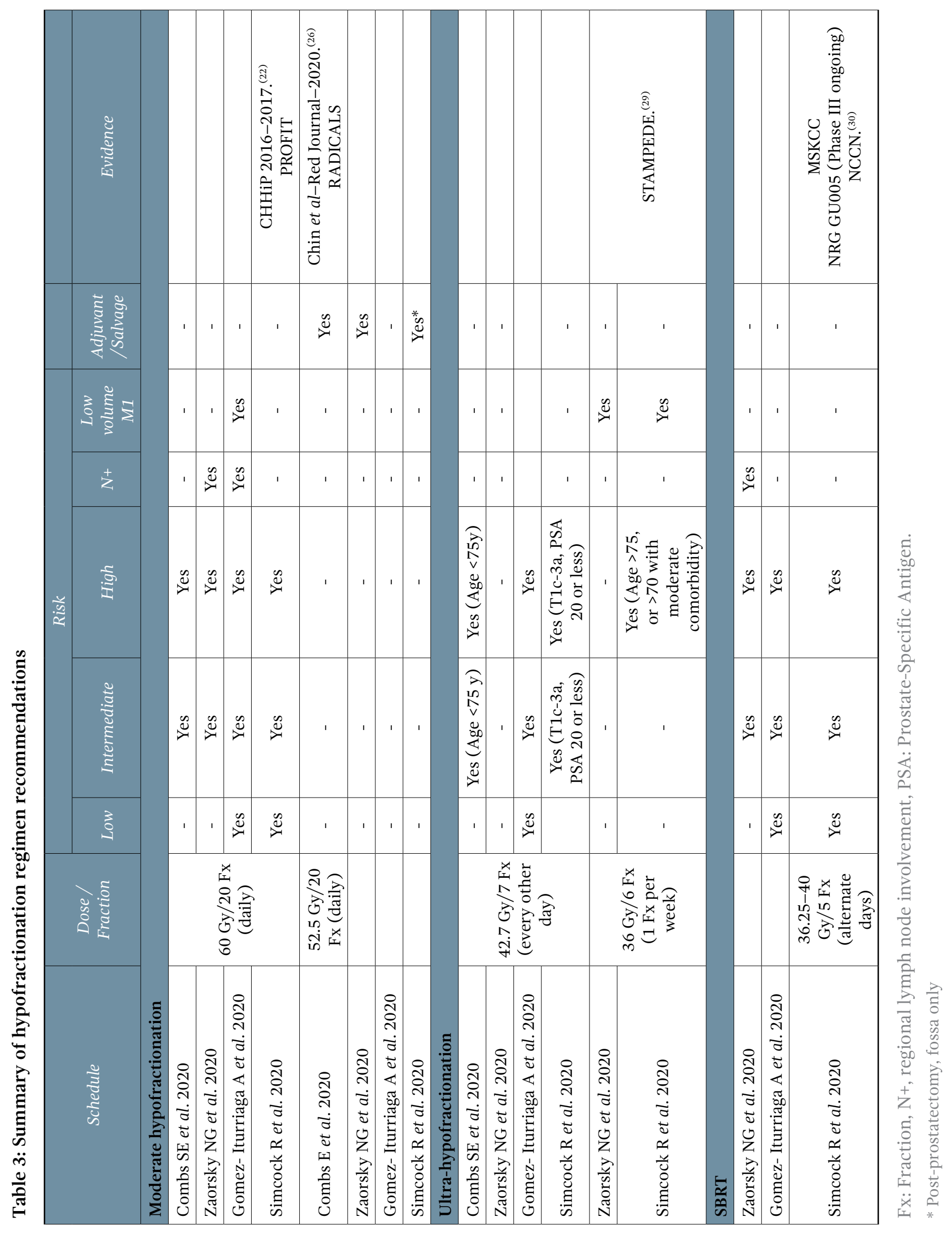


Finally, we presented a summary of treatment recommendations focusing on LMIE populations (Figure 1). It includes general recommendations, stage group-specific recommendations, and follow-up consultation guidance (Telemedicine).

Figure 1: Summary of recommendations for prostate cancer management during COVID-19

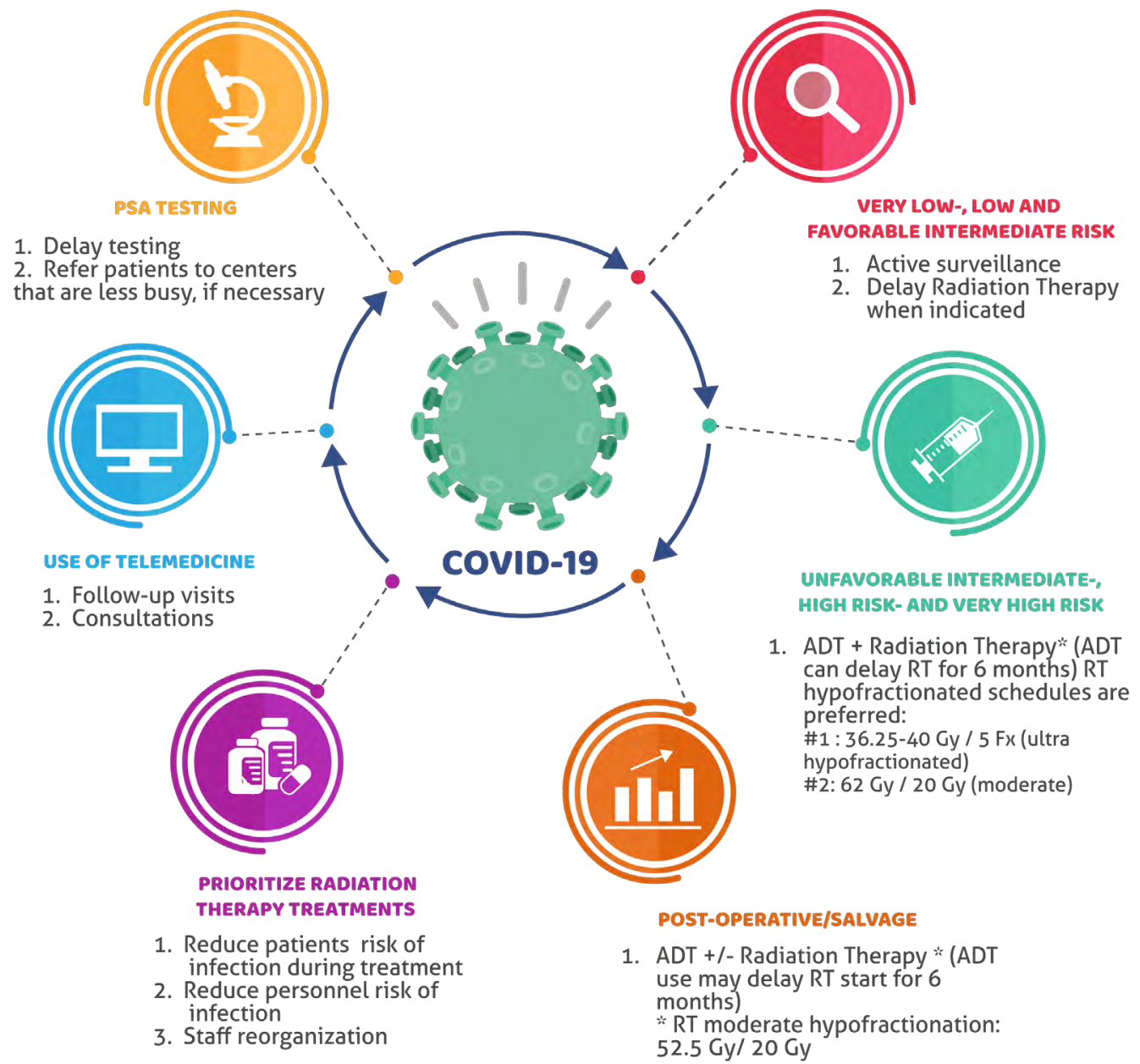

ADT: Androgen Deprivation Therapy, PSA: Prostate-Specific Antigen. *SBRT/Ultra-hypofractionation schedules should be performed only in centers with previous experience and available technology. 


\section{Discussion}

As the coronavirus pandemic continues to rise, new recommendations for the delivery of radiation therapy in prostate cancer are being developed. Radiation oncology departments in countries highly affected by SARS-CoV-2, such as Italy, are sharing their practice adaptations, ${ }^{(16,17)}$ and international radiation therapy collaboration groups and societies are providing new guidelines. ${ }^{(11-13)}$ Recommendations have been modeled after North American and European standards, but countries with LMIEs have had no significant representation in their development. To the best of our knowledge, no radiation oncology guidelines in countries with LMIEs have yet been issued. In this brief review, we have summarized recommendations and provided considerations for their implementation in LMIEs (Figure 1). In response to the unique and highly contagious behavior of COVID-19, most articles have included general recommendations for facing the pandemic, which include consultation/follow-up and unique treatment recommendations.

Overall, telemedicine for follow-up and in-treatment visits is being implemented. ${ }^{(11,15)}$ Telemedicine has previously been described as an effective alternative in prostate cancer for follow-up visits ${ }^{(31)}$ and it is crucial during the COVID-19 pandemic. To ensure its implementation, insurance services are including teleconsulting in their coverage (i.e., Medicare in the US). Concerns in countries with LMIEs arise, given the weaker health systems and lack of national and international guidelines with telemedicine regulations. ${ }^{(32,33)}$ Previous studies on mobile health for cancer in countries with LMIEs have not shown the promising results observed in HIE settings, and so additional efforts will need to be taken by the radiation oncologist to implement telemedicine in those LMIEs. ${ }^{(33,34)}$ Remote treatment planning is a safe strategy for reducing exposure of the medical staff (radiation oncologists, medical physicists, nurses) to the virus. However, the lack of software for remote treatment planning in countries with LMIEs lowers its feasibility during the pandemic, and radiotherapy administrators must try to provide and enhance the capacity of their centers to work remotely.

Prioritizing treatments as a critical strategy to reduce the number of patients and daily treatments per machine is being applied to other neoplasia in general radiation oncology practice. ${ }^{(9,11,15,35)}$ Prostate cancer is unique, as its usual progression permits safe treatment delay. Disease staging (risk groups) is critical for defining the suitability of the patient for treatment delay or postponement that will not compromise the oncologic outcome. In early-stage disease, current practice promotes active surveillance as the preferred treatment in very low and low-risk disease (Table 2). ${ }^{(18)}$ Although current guidelines do not have a preferred treatment during the pandemic in relation to favorable intermediate-risk disease, active surveillance is being adopted as the recommended modality, given that it has previously been shown to be a safe approach. (11-13,19) Because active surveillance requires periodic prostate-specific antigen (PSA) testing, patients should be referred to laboratories and centers that are less busy, to minimize their risks for exposure and infection.

Recommendations for advanced disease are particularly relevant in countries with LMIEs, where most patients are diagnosed in later disease stages and radical treatment is almost always imperative. ${ }^{(7,36)}$ For unfavorable 
and high-risk disease, radical treatment with radical prostatectomy or radiotherapy is usually required. Androgen deprivation therapy can be used to delay the start of said treatment. Recommendations for the duration of neoadjuvant ADT vary, with a maximum acceptable delay of 6 to 7 months, based on the previously published RTOG 9910 trial. ${ }^{(37)}$ Because a delay of 7 months is safe, schedules that reduce the number of hospital visits, such as 6-month subcutaneous delivery systems, are preferred. ${ }^{(38,39)}$ The availability of ADT could be more challenging in low-resource settings. We recommend that professionals keep a record of postponed treatments and ensure that all patients are safely getting the proper ADT doses.

Even before the current pandemic, radiotherapy for prostate cancer was developing towards hypofractionated schedules. ${ }^{(40,41)}$ During the SARS-CoV2 pandemic, that has become more relevant, so that the exposure of patients and medical staff to the virus can be reduced. ${ }^{(11-14,16)} \quad$ Ultra-hypofractionated radiotherapy is preferred for localized disease in the new recommendations (Table 3). ${ }^{(11-14)}$ Only two of the authors included in the review assessed the possible lack of technology and considered a 20 -fraction regimen that could be used in centers with no image-guided radiation therapy (IGRT) or previous experience in ultra-hypofractionation. ${ }^{(12,13)}$ Very few radiotherapy centers in countries with LMIEs have the technologic capacity and the necessary devices to administer ultra-hypofractionation in prostate cancer. ${ }^{(42)}$ Furthermore, the use of non-modulated three-dimensional conformal radiation therapy (3D-CRT) is not supported for the delivery of moderate hypofractionation. We believe hypofractionated schedules should be started if IGRT capacities are already in place, ${ }^{(43)}$ but even though hypofractionation is beneficial in reducing the number of hospital visits, it should not be implemented in centers that do not have previous experience or when high treatment conformation cannot be guaranteed. ${ }^{(12,13)}$

If IGRT is available, moderate hypofractionation is now more feasible in radiation oncology centers in countries with LMIEs. Hypofractionation should be a priority in those countries, not only during the present situation but afterwards, as well, because it enables broader machine availability and increases the capacity of the radiation oncology services. ${ }^{(44)}$ The adoption of the recommendations presented herein involves treatment postponement for most prostate cancer patients. Thus, after the crisis, the capacity of radiation therapy facilities may be overwhelmed. ${ }^{(11,45)}$ That situation becomes even more challenging in LMIE settings that have lower machine capacity and human workforce per capita, with one linear accelerator for 5 million inhabitants, compared with one for every 120,000 inhabitants in countries with HIEs. ${ }^{(44,46)}$

We suggest the following key points for implementing the newly formulated recommendations for prostate cancer during the pandemic in countries with LMIEs:

1. Consider hypofractionation regimens in intermediate and high-risk patients that require treatment. In centers with experience, stereotactic body radiation therapy (SBRT) can be considered. If available, we suggest the use of IGRT with daily cone beam imaging or daily $\mathrm{kV}$ imaging (with larger planning target volume (PTV) margins and no fiducials, to reduce invasive procedures during the pandemic). 
2. Remote treatment planning is a safe strategy for reducing exposure of the medical staff to the virus. Lack of software for remote treatment planning in countries with LMIEs lowers its feasibility. Radiotherapy administrators must make further efforts to provide and enhance the capacity of their centers to work remotely.

3. Stay updated on local data, estimating the peak of the pandemic, to decide when to delay or postpone treatment.

4. Keep a strict record of patients that are candidates for treatment postponement.

5. Provide a special informed consent statement, in which patients understand the risk and benefits of treatment postponement.

6. Make sure the patients have access to ADT. The availability of ADT could be more challenging in countries with LMIEs. Employ administration schedules that reduce the number of hospital visits.

7. Establish communication and work strategies with other local or national centers. Collaboration between centers can help in the response to staff reorganization or medical staff illness.

The aim of the present narrative review was not to change clinical practice, given that it does not follow a systematic review or clinical practice guideline methodology that evaluates quality and strength of recommendations (the GRADE system), but rather to provide radiation oncologists with a broad picture of the current recommendations and our own considerations for their implementation in low-to-middle-income economic settings.

\section{Conclusion}

Countries with LMIEs face significant challenges for adopting the present recommendations in relation to prostate cancer management during the SARS-CoV-2 pandemic. Of those recommendations, moderate hypofractionation is now more feasible, but it should only be implemented if IGRT capacities are already in place. Major challenges await due to the fact that treatment postponement could lead to the overwhelming of radiation oncology center capacity, once the pandemic has been controlled.

\section{Conflict of Interest:}

None

\section{Financial Source:}

None

Acknowledgements: The authors wish to thank Dr. Fabio Y. Morales for his valuable contribution to the revised version of the manuscript.

\section{Contributions}

All authors have made substantial contributions to the development of the study. Concept and design of the study was carried out by MCM and SGR. Data acquisition was carried out by MCM, and data analysis and interpretation were carried out by AGM and JCG. All authors contributed to the drafting of the article and a final critical review was carried out by AGM and JCG. The final version to be published was 
approved by JCG. We hereby certify that all authors have read and approved the manuscript's final version.

\section{References}

1. Organization WH. Coronavirus disease 2019 (COVID-19): situation report, 29. World Health Organization; 2020 Feb.

2. Liang W, Guan W, Chen R, Wang W, Li J, Xu K, et al. Cancer patients in SARS-CoV-2 infection: a nationwide analysis in China. The Lancet Oncology. 2020;21(3):335-7. doi: 10.1016/ S1470-2045(20)30096-6

3. Ueda M, Martins R, Hendrie PC, McDonnell T, Crews JR, Wong TL, et al. Managing Cancer Care During the COVID-19 Pandemic: Agility and Collaboration Toward a Common Goal. J Natl Compr Canc Netw. 2020;1-4. doi: 10.6004/ jnccn.2020.7560

4. Yom S, Zietman A. Radiation Therapy in a Time of Disaster Int J Radiat Oncol Biol Phys. 2018; 100:832-3. doi: 10.1016/j.ijrobp.2017.12.001

5. Sandler H. Role of Overall Treatment Time in the Management of Prostate Cancer Patients: How to Manage Unscheduled Treatment Interruptions. Int J Radiat Oncol Biol Phys. 2018;100(4):8412. doi: 10.1016/j.ijrobp.2017.12.278

6. Bray F, Ferlay J, Soerjomataram I, Siegel RL, Torre LA, Jemal A. Global cancer statistics 2018: GLOBOCAN estimates of incidence and mortality worldwide for 36 cancers in 185 countries. CA: A Cancer Journal for Clinicians. 2018;68(6):394-424. doi: 10.3322/caac.21492

7. World Health Organization. Global Cancer Observatory. International Agency for Research on Cancer. Available from: https://gco.iarc.fr/

8. Taitt HE. Global Trends and Prostate Cancer: A Review of Incidence, Detection, and
Mortality as Influenced by Race, Ethnicity, and Geographic Location: American Journal of Men's Health. 2018;12(6):1807-1823. doi: $10.1177 / 1557988318798279$

9. The European Society for Radiotherapy and Oncology. Radiotherapy in a time of crisis", ESTRO Presidents' statement. ESTRO.

10. Oncology TL. COVID-19: global consequences for oncology. The Lancet Oncology. 2020;21(4):467. doi: 10.1016/S14702045(20)30175-3

11. Simcock R, Thomas TV, Estes C, Filippi AR, Katz MS, Pereira IJ, et al. COVID-19: Global radiation oncology's targeted response for pandemic preparedness. ctRO. 2020 May 1;22:55-68. doi: 10.1016/j.ctro.2020.03.009

12. Zaorsky NG, Yu JB, McBride SM, Dess RT, Jackson WC, Mahal BA, et al. Prostate Cancer Radiation Therapy Recommendations in Response to COVID-19. Advances in Radiation Oncology. 2020;0(0).

13. Gomez-Iturriaga A, Conde A, Henríquez I, Gómez-Caamaño A, San-Segundo G, Torrecilla JL, et al. Abordaje del cáncer de próstata en los servicios de Oncología Radioterápica: recomendaciones URONCOR durante la pandemia y periodo de recuperación posterior. Sociedad Española de Oncología Radioterápica (SEOR); p. 13.

14. Combs SE, Belka C, Niyazi M, Corradini S, Pigorsch S, Wilkens J, et al. First statement on preparation for the COVID-19 pandemic in large German Speaking University-based radiation oncology departments. Radiation Oncology. 2020;15(1):74. doi: 10.1186/s13014020-01527-1

15. Filippi AR, Russi E, Magrini SM, Corvò R. Letter from Italy: First practical indications for radiation therapy departments during COVID-19 outbreak. International Journal of Radiation 


\section{Desafíos de los países con economías de bajo-a-mediano ingreso para el manejo... Caicedo-Martínez M., et al.}

Oncology, Biology, Physics. 2020;107(3):597-9. doi: 10.1016/j.ijrobp.2020.03.007

16. Achard V, Tsoutsou P, Zilli T. Letter from Switzerland. International Journal of Radiation Oncology, Biology, Physics. 2020;107(3):600-1. doi: $10.1016 /$ j.ijrobp.2020.03.008

17. Portaluri M, Tramacere F, PortaluriT, Gianicolo EAL. Southern Italy: How the Availability of Radiation Therapy, Patient Outcomes, and Risk to Health Care Providers Have Changed During the Coronavirus Disease 2019 Pandemic. Advances in Radiation Oncology. 2020;0(0). doi: 10.1016/j.adro.2020.03.016

18. Mohler JL, Horwitz E, Richey S. Guidelines Index Table of Contents Discussion. European Association of Urology; 2019 p. 165.

19. Neal DE, Metcalfe C, Donovan JL, Lane JA, Davis M, Young GJ, et al. Ten-year Mortality, Disease Progression, and Treatment-related Side Effects in Men with Localised Prostate Cancer from the ProtecT Randomised Controlled Trial According to Treatment Received. European Urology. 2020;77(3):320-30. doi: 10.1016/j. eururo.2019.10.030

20. Zapatero A, Guerrero A, Maldonado X, Alvarez A, Segundo CGS, Rodríguez MAC, et al. Highdose radiotherapy with short-term or longterm androgen deprivation in localised prostate cancer (DART01/05 GICOR): a randomised, controlled, phase 3 trial. The Lancet Oncology. 2015;16(3):320-7. doi: 10.1016/S14702045(15)70045-8

21. Bolla M, Maingon P, Carrie C, Villa S, Kitsios P, Poortmans PMP, et al. Short Androgen Suppression and Radiation Dose Escalation for Intermediate- and High-Risk Localized Prostate Cancer: Results of EORTC Trial 22991. JCO. 2016;34(15):1748-56. doi: 10.1200/ JCO.2015.64.8055
22. Dearnaley D, Syndikus I, Mossop H, Khoo V, Birtle A, Bloomfield D, et al. Conventional versus hypofractionated high-dose intensitymodulated radiotherapy for prostate cancer: 5-year outcomes of the randomised, noninferiority, phase $3 \mathrm{CHHiP}$ trial. The Lancet Oncology. 2016;17(8):1047-60. doi: 10.1016/ S1470-2045(16)30102-4

23. Widmark A, Gunnlaugsson A, Beckman L, Thellenberg-Karlsson C, Hoyer M, Lagerlund M, et al. Ultra-hypofractionated versus conventionally fractionated radiotherapy for prostate cancer: 5-year outcomes of the HYPORT-PC randomised, non-inferiority, phase 3 trial. The Lancet. 2019;394(10196):385-95. doi: 10.1016/S0140-6736(19)31131-6

24. Abdollah F, Dalela D, Sood A, Keeley J, Alanee S, Briganti A, et al. Impact of Adjuvant Radiotherapy in Node-positive Prostate Cancer Patients: The Importance of Patient Selection. European Urology. 2018;74(3):253-6. doi: 10.1016/j.eururo.2018.04.017

25. Lieng $\mathbf{H}$, Kneebone A, Hayden AJ, Christie DRH, Davis BJ, Eade TN, et al. Radiotherapy for node-positive prostate cancer: 2019 Recommendations of the Australian and New Zealand Radiation Oncology Genito-Urinary group. Radiotherapy and Oncology. 2019; 140:68-75. doi: 10.1016/j.radonc.2019.05.016

26. Chin S, Fatimilehin A, Walshaw R, Argarwal A, Mistry $\mathbf{H}$, Elliott $\mathbf{T}$, et al. Ten-Year Outcomes of Moderately Hypofractionated Salvage Postprostatectomy Radiation Therapy and External Validation of a Contemporary Multivariable Nomogram for Biochemical Failure. International Journal of Radiation Oncology, Biology, Physics. 2020;107(2):28896. doi: 10.1016/j.ijrobp.2020.01.008 
Desafíos de los países con economías de bajo-a-mediano ingreso para el manejo... Caicedo-Martínez M., et al.

27. Segundo CG-S, Couñago F, Gomez-Iturriaga A. Androgen Deprivation Therapy and Salvage Radiotherapy: Are We Missing Something? European Urology. 2019;76(2):260-1. doi: 10.1016/j.eururo.2019.01.045

28. Ghadjar P, Aebersold DM, Albrecht C, Böhmer $D$, Flentje M, Ganswindt U, et al. Use of androgen deprivation and salvage radiation therapy for patients with prostate cancer and biochemical recurrence after prostatectomy. Strahlenther Onkol. 2018;194(7):619-26. doi: $10.1007 / \mathrm{s} 00066-018-1269-3$

29. Parker CC, James ND, Brawley CD, Clarke NW, Hoyle AP, Ali A, et al. Radiotherapy to the primary tumour for newly diagnosed, metastatic prostate cancer (STAMPEDE): a randomised controlled phase 3 trial. The Lancet. 2018;392(10162):2353-66. doi: 10.1016/ S0140-6736(18)32486-3

30. Zelefsky MJ, Kuban DA, Levy LB, Potters L, Beyer DC, Blasko JC, et al. Multi-institutional analysis of long-term outcome for stages T1-T2 prostate cancer treated with permanent seed implantation. International Journal of Radiation Oncology, Biology, Physics. 2007;67(2):327-33. doi: 10.1016/j.ijrobp.2006.08.056

31. Frankland J, Brodie H, Cooke D, Foster C, Foster R, Gage H, et al. Follow-up care after treatment for prostate cancer: evaluation of a supported self-management and remote surveillance programme. BMC Cancer. 2019;19(1):368. doi: 10.1186/s12885-019-5561-0

32. Ohannessian R, Duong TA, Odone A. Global Telemedicine Implementation and Integration Within Health Systems to Fight the COVID-19 Pandemic: A Call to Action. JMIR Public Health and Surveillance. 2020;6(2):e18810. doi: $10.2196 / 18810$

33. Holeman I, Evans J, Kane D, Grant L, Pagliari C, Weller D. Mobile health for cancer in low to middle income countries: priorities for research and development. Eur J Cancer Care. 2014;23(6):750-6. doi: 10.1111/ecc.12250

34. Bhatt S, Evans J, Gupta S. Barriers to Scale of Digital Health Systems for Cancer Care and Control in Last-Mile Settings. Journal of Global Oncology. 2017;4: JGO.2016.007179. doi: 10.1200/JGO.2016.007179

35. Braunstein LZ, Gillespie EF, Hong L, Xu A, Bakhoum SF, Cuaron J, et al. Breast Radiation Therapy Under COVID-19 Pandemic Resource Constraints-Approaches to Defer or Shorten Treatment from a Comprehensive Cancer Center in the United States. Advances in Radiation Oncology. 2020;0(0). doi: 10.1016/j. adro.2020.03.013

36. Allemani C, Matsuda T, Carlo VD, Harewood R, Matz M, Nikši】 M, et al. Global surveillance of trends in cancer survival 2000-14 (CONCORD-3): analysis of individual records for 37513025 patients diagnosed with one of 18 cancers from 322 populationbased registries in 71 countries. The Lancet. 2018;391(10125):1023-75. doi: 10.1016/ S0140-6736(17)33326-3

37. Pisansky TM, Suman VJ, Roach M, Sandler HM. Reporting of results in DART01/05 GICOR. The Lancet Oncology. 2015;16(6):e258. doi: 10.1016/S1470-2045(15)70243-3

38. Carneiro A, Wroclawski ML, Nahar B, Soares A, Cardoso AP, Kim NJ, et al. Impact of the COVID-19 Pandemic on the Urologist's clinical practice in Brazil: a management guideline proposal for low- and middle-income countries during the crisis period. Int Braz J Urol. 2020;501-10.

39. Crawford ED, Sartor O, Chu F, Perez R, Karlin G, Garrett JS. A 12-month clinical study of LA-2585 (45.0 mg): a new 6-month subcutaneous delivery system for leuprolide 


\section{Desafíos de los países con economías de bajo-a-mediano ingreso para el manejo... Caicedo-Martínez M., et al.}

acetate for the treatment of prostate cancer. J Urol. 2006;175(2):533-6. doi: 10.1016/S00225347(05)00161-8

40. Morgan SC, Hoffman K, Loblaw DA, Buyyounouski MK, Patton C, Barocas D, et al. Hypofractionated Radiation Therapy for Localized Prostate Cancer: Executive Summary of an ASTRO, ASCO, and AUA Evidence-Based Guideline. Practical Radiation Oncology. 2018;8(6):354-60. doi: 10.1016/j. prro.2018.08.002

41. Höcht S, Aebersold DM, Albrecht C, Böhmer D, Flentje M, Ganswindt U, et al. Hypofractionated radiotherapy for localized prostate cancer. Strahlenther Onkol. 2017;193(1):1-12. doi: 10.1007/s00066-016-1041-5

42. Rosenblatt E, Zubizarreta E. Radiotherapy in Cancer Care: Facing the Global Challenge. Vienna: International Atomic Energy Agency; 2017. 578 p.
43. American Urological Association. Prostate Cancer: Hypofractionated Radiotherapy Guideline An ASTRO, ASCO, and AUA Evidence-Based Guideline. American Urological Association. 2018.

44. Rosenblatt E, Acuña O, Abdel-Wahab M. The Challenge of Global Radiation Therapy: An IAEA Perspective. International Journal of Radiation Oncology, Biology, Physics. 2015;91(4):687-9. doi: 10.1016/j.ijrobp.2014.12.008

45. Burki TK. Cancer guidelines during the COVID-19 pandemic. The Lancet Oncology. 2020;21(5):629-30. doi: 10.1016/S14702045(20)30217-5

46. Atun R, Jaffray DA, Barton MB, Bray F, Baumann M, Vikram B, et al. Expanding global access to radiotherapy. The Lancet Oncology. 2015;16(10):1153-86. doi: 10.1016/S14702045(15)00222-3 